INTERLEUKIN (IL)-15 has emerged as a key regulator of both natural killer (NK) cell differentiation and activation. The aim of the present study was to investigate the expansion of the population of cells expressing killer-cell immunoglobulin-like receptors (CD158a and CD158b) in human peripheral lymphocytes by treatment with IL-15. One million peripheral lymphocytes were cultured in RPMI1640 medium alone or in medium containing IL- 2 at $100 \mathrm{U} / \mathrm{ml}$ or IL15 at $0.1,1.0$, or $10.0 \mathrm{ng} / \mathrm{ml}$ for $48 \mathrm{~h}$. After each incubation, we assessed the natural killing activity

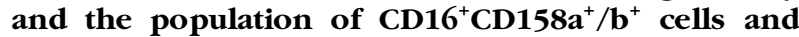
$\mathrm{CD8}^{+} \mathrm{CD} 158 \mathrm{a}^{+} / \mathrm{b}^{+}$cells. IL-15 increased the NK activity and expanded the populations of $\mathrm{CD}^{+} \mathrm{CD}^{+} \mathrm{Craa}^{+} / \mathrm{b}^{+}$

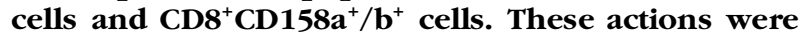
dose dependent, and the effects of IL-15 at $1.0 \mathrm{ng} / \mathrm{ml}$ were close to those of IL-2 at $100 \mathrm{U} / \mathrm{ml}$. These findings suggest that IL-15 induces the effector functions of resting NK cells throughout the body, and thereby plays a critical role in the activation of tissueassociated immune responses.

Key words: Killer-cell immunoglobulin-like receptors, IL15, Natural killer cell activation

\section{The effect of interleukin-15 on the expression of killer-cell immunoglobulin-like receptors on peripheral natural killer cells in human}

\author{
Toshiaki Kogure ${ }^{1,2, C A}$, Naoki Mantani ${ }^{1,2}$, \\ Hirozo Goto ${ }^{3}$, Yutaka Shimada', Jun'ichi Tamura ${ }^{4}$ \\ and Katsutoshi Terasawa ${ }^{1}$
}

'Department of Japanese Oriental Medicine, Faculty of Medicine, and ${ }^{3}$ Department of Kampo Diagnosis, Institute of Natural Medicine, Toyama Medical and Pharmaceutical University, 2630 Sugitani, Toyama 930-0194, Japan; ${ }^{2}$ Department of Integrated Japanese Oriental Medicine, and ${ }^{4}$ Department of General Medicine, School of Medicine, Gunma University, 3-39-22 Showa-machi, Maebashi city, Gunma 371-8511, Japan.

${ }^{\mathrm{CA}}$ Corresponding author
Tel/Fax: +81 272208666
E-mail: tkogure@showa.gunma-u.ac.jp

\section{Introduction}

Since the molecular cloning of natural killer (NK) receptors was achieved in $1995,{ }^{1-3}$ it has subsequently been shown that these receptors, which are now called killer cell immunoglobulin-like receptors (KIRs), transmit positive and/or negative signals. ${ }^{4,5}$ It is now widely accepted that the expression of KIRs is involved in the cytolytic function of NK cells, as demonstrated by a number of studies focusing on these receptors. ${ }^{6,7}$ Analysis of KIR expression has contributed to revealing the regulation and function of NK cell activation.

Interleukin (IL)-15 was discovered in 1994 and shown to have the potential to enhance cell-mediated immune responses to intracellular pathogens and tumors. ${ }^{89}$ IL-15 shares no homology with IL-2, but IL15 shares many of the biologic activities of IL-2, including induction of the proliferation of phytohemagglutinin-stimulated normal peripheral blood mononuclear cells (PBMC), NK cells, B cells, and T cells, and generation of allogenic cytotoxic T lymphocytes in vitro. ${ }^{8-13}$
Although IL-2 and IL-15 are lymphocyte growth factors with overlapping functions in immune responses, the cells that produce IL-15 are different from those that produce IL-2. IL-2 is produced by activated T cells, while in contrast IL-15 is produced by epithelial cells and macrophages, which range over the whole body. ${ }^{8}$ Thus, it is considered that IL15 maintains $T$ cells, diminishes the occurrence of malignant tumors and defends against microbial infections, and that these actions are partly due to the enhancement of the function of NK cells by IL15. Indeed, IL-15 is an essential regulator of the differentiation of NK cells from stem cells, ${ }^{14-16}$ and moreover IL-15 can stimulate or augment the activation of mature human NK cells. ${ }^{17}$ However, little is known about the effects of IL-15 on the expression of NK receptors, which are involved in NK cell regulation.

The aim of the present study was to assess the effect of IL-15 on the expression of KIRs on mature $\mathrm{NK}$ cells $\left(\mathrm{CD}^{+} 6^{+}\right)$and $\mathrm{CD}^{+} \mathrm{T}$ cells to clarify the mechanism of NK cell regulation by IL-15. 


\section{Methods}

\section{Reagents}

Fluorescein isothiocyanate (FITC)-conjugated antihuman CD8, FITC-anti-human CD16, phycoerythrin (PE)-conjugated anti-human CD158a and PE-conjugated anti-human $\mathrm{CD} 158 \mathrm{~b}$ were purchased from Immunotech (Marseille, France). Recombinant human IL-2 was obtained from Pharmabiotechnology (Hannover, Germany). Recombinant human IL-15 was purchased from Strathmann Biotech (Hamburg, Germany).

\section{Cells}

PBMC obtained from 10 healthy subjects were separated from heparinized blood by Lymphoprep (Nyegaard, Oslo, Norway) gradient cenfugation. ${ }^{18}$ Each PBMC sample was incubated in a culture dish in a humidified $5 \% \mathrm{CO}_{2} / 95 \%$ air atmosphere at $37^{\circ} \mathrm{C}$ for $60 \mathrm{~min}$. After the incubation, non-adherent cells were collected and washed twice in phosphate-buffered saline.

\section{Cell culture}

One million cells were cultured in RPMI 1640 medium supplemented with $10 \%$ fetal calf serum (Biological Industries, Israel) in tissue culture dishes (Becton Dickinson, Franklin, NJ, USA). The cell cultures were incubated in medium only or medium supplemented with IL-2 at $100 \mathrm{U} / \mathrm{ml}$ or IL-15 at 0.1 , 1.0 , or $10.0 \mathrm{ng} / \mathrm{ml}$ in a humidified $5 \% \mathrm{CO}_{2} / 95 \%$ air atmosphere at $37^{\circ} \mathrm{C}$ for $48 \mathrm{~h}$. After each incubation, cells were collected and their surface antigens were analyzed using flow cytometry (Epics XL; Beckman Coulter, France). Each experiment was carried out in duplicate.

\section{Cell phenotype}

Surface phenotyping was carried out using a twocolor immunofluorescence staining technique, with isotype-specific mouse anti-human antibody conjugated with either FITC or PE. ${ }^{19}$ Each sample of stained cells was suspended in $0.5 \mathrm{ml}$ of phosphate-buffered saline and analyzed by flow cytometry. Lymphocyte subsets were identified by gating analysis, and fluores- cence profiles were obtained for 10,000 cells of each sample. Negative controls for each experiment were performed with FITC- and PE-labeled mouse immunoglobulin G.

\section{NK cytolytic activity}

NK activity was assessed against K562, a myelogenous leukemia cell line, in a 3 -h ${ }^{51} \mathrm{Cr}$-release assay as described previously. The effector cells were mixed with labeled target cells at various cell concentrations to give an effector-to-target ratio of 20:1 or 10:1. Duplicate samples were prepared for each ratio. The supernatants were withdrawn after a 4 -h incubation period, and the ${ }^{51} \mathrm{Cr}$ released from lysed target cells was quantitated in a gamma counter (Packard Instrument Co., Boston, MA, USA). Incubation of target cells with medium or saponin $(7 \mathrm{mg} / \mathrm{ml})$ and ethylenediamine tetraacetic acid $(0.1 \mathrm{mg} / \mathrm{ml})$ was used to determine spontaneous and maximal release, respectively. The percent cytotoxicity was calculated by the formula: (cpm of effector cells - cpm of spontaneous release $) /(\mathrm{cpm}$ of maximal release $-\mathrm{cpm}$ of spontaneous release) $\times 100$.

\section{Statistical analysis}

Data are expressed as mean (standard deviation) values. All data were collected in a computer database and analyzed using the StatView-J 4.02 program (Abacus Concept, Berkeley, CA, USA). The Wilcoxon signed-rank test was performed for each set of data for NK activity and surface antigen expression. For all statistical tests, differences were regarded as statistically significant at $p<0.05$.

\section{Results}

Enhancement of NK cytolytic activity by IL-15

To confirm the ability of IL-15 to elevate the natural killing activity, we measured the NK activity after incubation ( $48 \mathrm{~h}$ ) with IL-15 (concentration, 0.1, 1.0, or $10.0 \mathrm{ng} / \mathrm{ml}$ ). The results are presented in Table 1 . At $0.1 \mathrm{ng} / \mathrm{ml}$ of IL-15, the NK activity was significantly increased compared with medium alone. The increase of NK cytolytic activity by treatment with IL-15 was

Table 1. Natural killing activity (\%) after treatment ( $48 \mathrm{~h}$ ) with IL-2 or IL-15

\begin{tabular}{|c|c|c|c|c|c|}
\hline \multirow[t]{2}{*}{ Effector/target } & \multirow[t]{2}{*}{ Medium alone } & \multirow{2}{*}{$\frac{\mathrm{IL}-2}{100 \mathrm{U} / \mathrm{ml}}$} & \multicolumn{3}{|c|}{ IL-15 } \\
\hline & & & $0.1 \mathrm{ng} / \mathrm{ml}$ & $1.0 \mathrm{ng} / \mathrm{ml}$ & $10.0 \mathrm{ng} / \mathrm{ml}$ \\
\hline $\begin{array}{l}10 / 1 \\
20 / 1\end{array}$ & $\begin{array}{r}6.5 \pm 3.2 \\
12.2 \pm 4.8\end{array}$ & $\begin{array}{l}25.8 \pm 15.6^{*} \\
36.2 \pm 16.4^{*}\end{array}$ & $\begin{array}{l}11.6 \pm 4.2^{*} \\
20.3 \pm 6.4^{*}\end{array}$ & $\begin{array}{l}24.3 \pm 6.9^{*} \\
34.7 \pm 5.7^{*}\end{array}$ & $\begin{array}{l}46.3 \pm 8.5^{*} \# \\
64.5 \pm 14.4^{*} \#\end{array}$ \\
\hline
\end{tabular}

${ }^{*} p<0.05$ versus medium alone, $\# p<0.05$ versus IL-2 $100 \mathrm{U} / \mathrm{ml}$. 

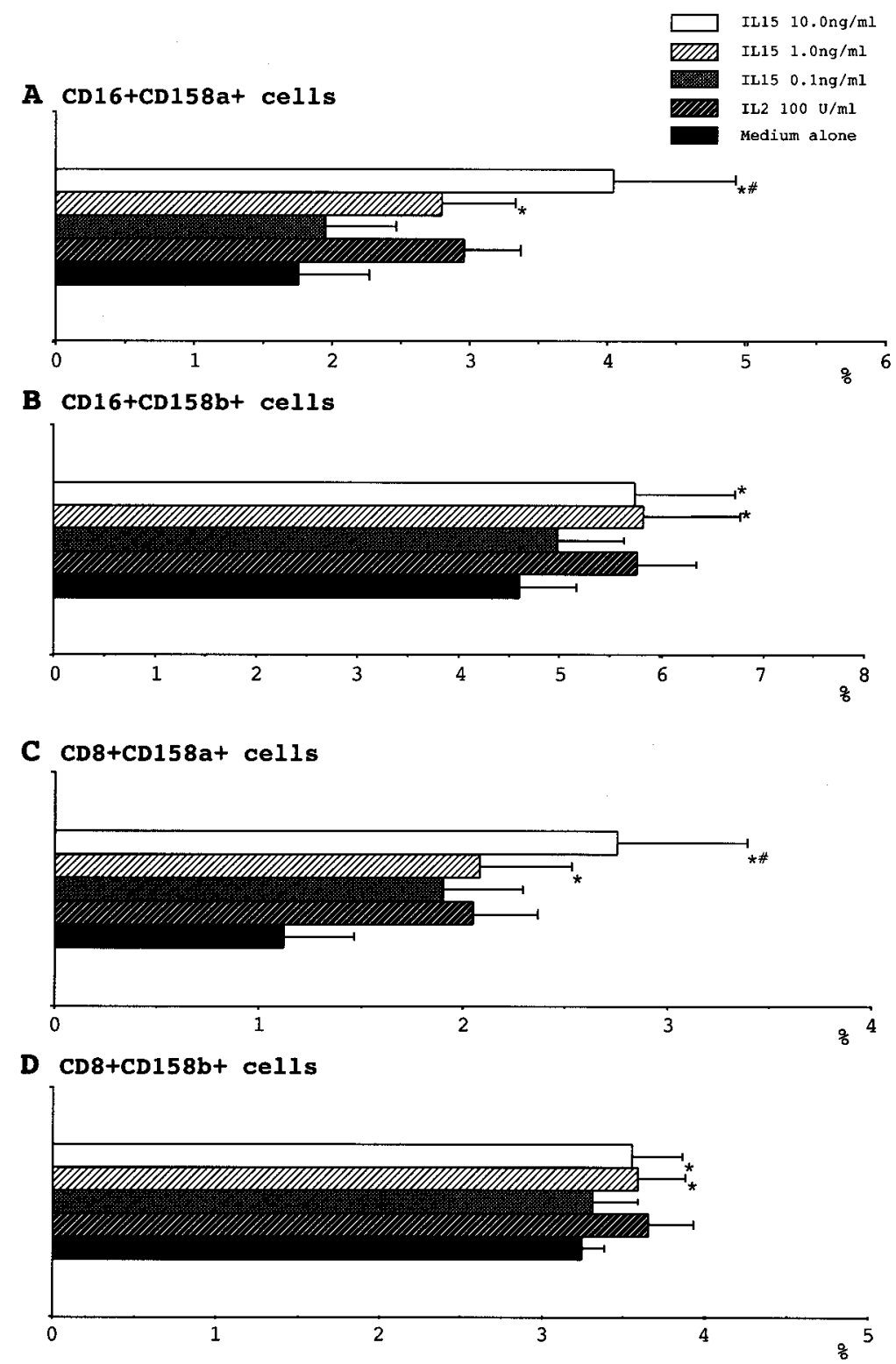

FIG. 1. The expansion of cells expressing KIRs in human peripheral lymphocytes by IL-15 or IL-2. Peripheral lymphocytes were cultured in medium alone or medium supplemented with IL-2 at $100 \mathrm{U} / \mathrm{ml}$ or with IL-15 at $0.1,1.0$, or $10.0 \mathrm{ng} / \mathrm{ml}$ for $48 \mathrm{~h}$. After each incubation, the populations of $C D 16^{+} \mathrm{CD} 158 \mathrm{a}^{+} / \mathrm{b}^{+}$and $\mathrm{CD} 8^{+} \mathrm{CD} 158 \mathrm{a}^{+} / \mathrm{b}^{+}$cells were measured using flow cytometry. (A): $C D 16^{+} \mathrm{CD} 158 \mathrm{a}^{+}$cells. Both 1.0 and $10.0 \mathrm{ng} / \mathrm{ml}$ of IL-15 significantly expanded this population. These effects of IL-15 were dose dependent from 0.1 to $10.0 \mathrm{ng} / \mathrm{ml}$ in vitro. (B): CD16 CD158 ${ }^{+}$cells. Both 1.0 and $10.0 \mathrm{ng} / \mathrm{ml}$ of IL-15 significantly expanded this population although there was no difference between the effects of 1.0 and $10.0 \mathrm{ng} / \mathrm{ml}$ of IL-15. (C): $\mathrm{CD} 8{ }^{+} \mathrm{CD} 158 \mathrm{a}^{+}$cells. Both 1.0 and $10.0 \mathrm{ng} / \mathrm{ml}$ of IL-15 significantly expand this population, and the effect of $1.0 \mathrm{ng} / \mathrm{ml}$ of IL-15 was nearly equal to that of $100 \mathrm{U} / \mathrm{ml}$ of IL-2. (D): CD8 ${ }^{+}$CD $158 \mathrm{~b}^{+}$cells. Both 1.0 and $10.0 \mathrm{ng} / \mathrm{ml}$ of IL-15 significantly expanded this population, although there was no difference between the effects of 1.0 and $10.0 \mathrm{ng} / \mathrm{ml} \mathrm{IL}-15$. ${ }^{*} p<0.05 \mathrm{versus}$ medium alone \# $p<0.05$ versus $100 \mathrm{U} / \mathrm{ml}$ of IL-2

dose dependent from 0.1 to $10 \mathrm{ng} / \mathrm{ml}$. The effect of $1.0 \mathrm{ng} / \mathrm{ml}$ of IL- 15 was similar to that of $100 \mathrm{U} / \mathrm{ml}$ of IL2 , and $10 \mathrm{ng} / \mathrm{ml}$ of IL-15 significantly elevated the NK activity compared with $100 \mathrm{U} / \mathrm{ml}$ of IL-2.

\section{Expansion of the CD $16^{+} \mathrm{CD} 158 \mathrm{a} / \mathrm{b}^{+}$cell population by IL-15}

The signals from KIRs play a crucial role in NK cell regulation, and therefore we investigated the populations of CD158a-positive and CD158b-positive cells.
IL-15 at $1.0 \mathrm{ng} / \mathrm{ml}$ expanded the population of $\mathrm{CD} 16^{+} \mathrm{CD} 158 \mathrm{a}^{+}$cells significantly, and this effect was nearly to equal to that of $100 \mathrm{U} / \mathrm{ml}$ of IL-2 (Fig. 1). The expansion of $\mathrm{CD}_{16} 6^{+} \mathrm{CD} 158 \mathrm{a}^{+}$cells by treatment with IL-15 was dose dependent from 0.1 to $10 \mathrm{ng} / \mathrm{ml}$. IL-15 also expanded the population of $\mathrm{CD}_{16} 6^{+} \mathrm{CD} 158 \mathrm{~b}^{+}$ cells, but the effect of $10 \mathrm{ng} / \mathrm{ml}$ of IL- 15 was not different from that of $1.0 \mathrm{ng} / \mathrm{ml}$ of IL- 15 or $100 \mathrm{U} / \mathrm{ml}$ of IL-2 (Fig. 1). The populations of $\mathrm{CD}^{+} \mathrm{CD} 158 \mathrm{a}^{+}$cells and $\mathrm{CD}^{+} \mathrm{CD} 158 \mathrm{~b}^{+}$cells were expanded similarly to those of the respective $\mathrm{CD} 6^{+}$cells by IL-15. In 

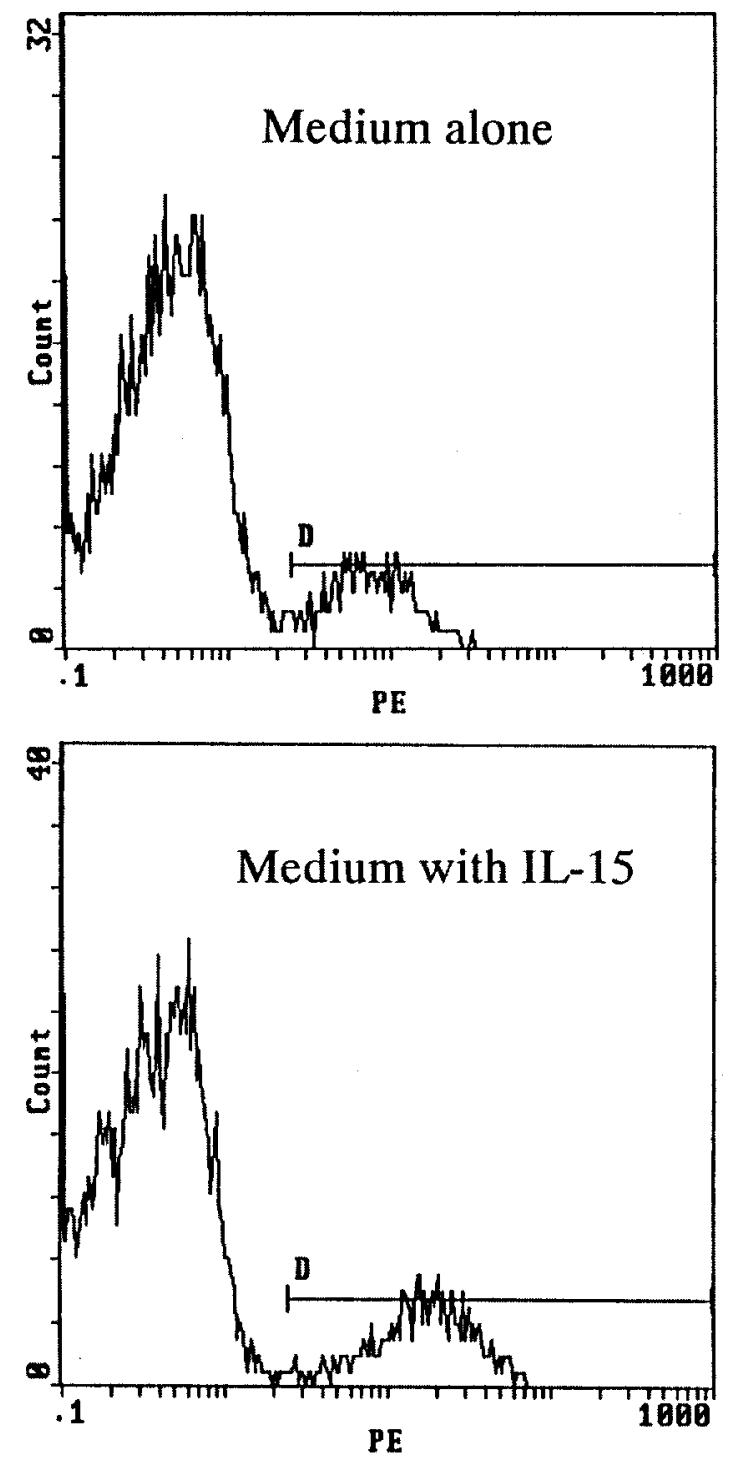

FIG. 2. The change of the KIRs expression per cell in response to IL-15. Representative data using PE-labeled CD158b was shown. Upper panel, medium alone; lower panel, medium with $10 \mathrm{ng} / \mathrm{ml}$ of IL-15. The population of CD158b-positive cell was $8.7 \%$ in medium alone, and $9.7 \%$ under the condition in medium with $10 \mathrm{ng} / \mathrm{ml}$ of IL- 15 . Especially, the intensity of PE was higher in medium with $10 \mathrm{ng} / \mathrm{ml}$ of IL-15 than in medium alone. These phenomena indicated that the CD158b molecule on each lymphocyte was upregulated. contrast, the total populations of $\mathrm{CDB}^{+}$cells and $\mathrm{CD} 16^{+}$cells were not changed by treatment with $\mathrm{IL}^{-}$ 15 (data not shown).

In addition, we further analyzed the change in the expression per cell of KIRs in response to IL-15. The representative data was shown in Fig. 2. The CD158b molecule on each lymphocyte were upregulated.

The change of the percentage of $C D 158 a^{+} / b^{+}$ cells in $\mathrm{CD}^{+}$or $\mathrm{CD}^{+} 6^{+}$cells by IL- 15

IL-15 treatment at each concentration tested increased the percentage of $\mathrm{CD} 158 \mathrm{a}^{+} / \mathrm{b}^{+}$cells in $\mathrm{CD} 16^{+}$cells. IL-15 at $10 \mathrm{ng} / \mathrm{ml}$ significantly increased the percentage of such cells in comparison with medium alone. The percentage of CD158a- and CD158b-expressing cells among $\mathrm{CD}^{+}$cells was also increased by treatment with $10 \mathrm{ng} / \mathrm{ml}$ of IL-15 (Table 2).

\section{Discussion}

IL-15 has been reported to exert proliferative effects on T-cell lines and to share many biologic properties with IL-2. ${ }^{8,9,11}$ At optimal concentrations, IL-15 rapidly induces memory $\left(\mathrm{CD} 45 \mathrm{RO}^{+}\right) \mathrm{CD}^{+}$and $\mathrm{CD}^{+}$ $\mathrm{T}$ cells and naive $\left(\mathrm{CD} 45 \mathrm{RO}^{-}\right) \mathrm{CD}^{+} \mathrm{T}$ cells to express the CD69 activation marker, followed by proliferation. However, IL-15 appears to have no chemokinetic or chemotactic activity on human monocytes or neutrophils. ${ }^{20,21}$ In the present study, the population of $\mathrm{CD}^{+}$cells was not expanded by the treatment with IL-15. Instead, the population of activated T lymphocytes probably increased.

As for NK cells, the proliferation, survival, and effector functions of resting NK cells are induced by exogeneous IL-15..$^{9,17}$ In vitro, IL-15 induces the cytotoxic activity of NK cells as well as T cells. ${ }^{15,22}$ Our data also demonstrated that IL-15 enhances NK activity. Although the degree of its ability to enhance the NK activity varies depending on the report, it appeared to be more effective than IL-2 in the present study. The biological functions of IL-15 are similar to

Table 2. The percentage of $\mathrm{CD} 158 \mathrm{a}^{+} / \mathrm{b}^{+}$cells in $\mathrm{CD}_{16}{ }^{+}$or $\mathrm{CD} 8^{+}$cells after treatment $(48 \mathrm{~h})$ of IL-2 and IL-15

\begin{tabular}{|c|c|c|c|c|c|}
\hline \multirow[t]{2}{*}{ Effector/target } & \multirow[t]{2}{*}{ Medium alone } & \multirow{2}{*}{$\frac{\mathrm{IL}-2}{100 \mathrm{U} / \mathrm{ml}}$} & \multicolumn{3}{|c|}{ IL-15 } \\
\hline & & & $0.1 \mathrm{ng} / \mathrm{ml}$ & $1.0 \mathrm{ng} / \mathrm{ml}$ & $10.0 \mathrm{ng} / \mathrm{ml}$ \\
\hline \multicolumn{6}{|l|}{ CD16 ${ }^{+}$cells } \\
\hline $\mathrm{CD}^{16}{ }^{+} \mathrm{CD} 158 \mathrm{a}^{+}$cells & $8.7 \pm 7.0$ & $13.3 \pm 8.0$ & $9.8 \pm 4.4$ & $12.6 \pm 8.6$ & $20.6 \pm 11.2^{*}$ \\
\hline $\mathrm{CD} 16^{+} \mathrm{CD} 158 \mathrm{~b}^{+}$cells & $25.3 \pm 6.1$ & $28.4 \pm 7.2$ & $26.6 \pm 6.3$ & $29.6 \pm 6.8$ & $32.5 \pm 9.3^{*}$ \\
\hline \multicolumn{6}{|l|}{$\mathrm{CD}^{+}$cells } \\
\hline $\mathrm{CD}^{+} \mathrm{CD} 158 \mathrm{a}^{+}$cells & $4.3 \pm 4.6$ & $7.5 \pm 7.3$ & $5.9 \pm 6.0$ & $7.0 \pm 7.8$ & $11.2 \pm 7.4^{*}$ \\
\hline $\mathrm{CD}^{+}{ }^{+} \mathrm{CD} 158 \mathrm{~b}^{+}$cells & $10.3 \pm 2.2$ & $12.1 \pm 3.3$ & $11.0 \pm 3.1$ & $11.7 \pm 3.5$ & $13.2 \pm 4.2^{*}$ \\
\hline
\end{tabular}

\footnotetext{
* $p<0.05$ versus medium alone.
} 
those of IL-2, but they have some different characteristics. First, when the cytotoxicity of $\mathrm{T}$ cells is enhanced by IL-2 or IL-15, IL-15 promotes their survival while IL-2 predisposes activated T cells to die by apoptosis. ${ }^{23}$ Second, IL-2 and IL-15 are produced by different cell types, namely epithelial cells, monocytes or macrophages produce IL-15, while in contrast, IL-2 is produced by activated T cells. Therefore, it is suggested that IL-15 has a general role in the activation of innate and tissue-associated immune responses.

It is now widely accepted that NK cells recognize and lyse target cells through the interplay of two families of receptors. ${ }^{24-26}$ One family consists of killer-cell activating receptors such as $\mathrm{CD}^{2} 9^{27}$ and $2 \mathrm{~B} 4,{ }^{28}$ and the other consists of KIRs. The activating signal can be over-ridden by a dominant-negative signal from a KIR when the KIR interacts with its ligand on the target cell, although activating receptors, when occupied, trigger lysis of the target cell being recognized. Recently, it has been reported that KIR downregulation on NK cells is associated with the downregulation of activating receptors, ${ }^{29}$ and there is a biphasic response of NK cells expressing KIRs, in which high expression of CD158b transmits inhibitory signals to NK cells whereas low expression transmits activating signals. ${ }^{30}$ These facts indicate that signals from NK receptors play important roles in NK cell regulation. Therefore, we further analyzed the effects of IL-15 on the expression of KIRs recognized by CD158a/b. Our findings demonstrated that IL-15 expanded the populations of both $\mathrm{CD} 16^{+} \mathrm{CD} 158 \mathrm{a}^{+} / \mathrm{b}^{+}$cells and $\mathrm{CD}^{+} \mathrm{CD} 158 \mathrm{a}^{+} / \mathrm{b}^{+}$cells. In addition, the expression per cell of these KIRs in response to IL-15 was upregulated. The expansions of $\mathrm{CD}_{16} 6^{+} \mathrm{CD} 158 \mathrm{a}^{+}$or $\mathrm{CD}^{+} \mathrm{CD} 158 \mathrm{~b}^{+}$cells were dose dependent from 0.1 to $10 \mathrm{ng} / \mathrm{ml}$, as was the increase of NK cytolytic activity by treatment with IL-15. In contrast, while the expansions of the $\mathrm{CD}^{158 \mathrm{~b}^{+}}$cell population was dose dependent from 0.1 to $1.0 \mathrm{ng} /$ $\mathrm{ml}$, there was no significant difference between the effect of $10 \mathrm{ng} / \mathrm{ml}$ and that of $1.0 \mathrm{ng} / \mathrm{ml}$. We considered that further expansion of $\mathrm{CD} 158 \mathrm{~b}^{+}$cells did not occur despite the increase of NK activity by $10 \mathrm{ng} / \mathrm{ml}$ compared with $1.0 \mathrm{ng} / \mathrm{ml}$ because the NK activity is dependent on several signals from NK receptors. However, it is difficult to explain the difference between the responses of the CD158a and $\mathrm{CD} 158 \mathrm{~b}$ molecules. The possible shared functions of the CD158a and CD158b molecules are still not known, although it is well known that their ligands are different.

To investigate the effects of IL-15 on the expression of KIRs on $\mathrm{CD}^{+}$cells and $\mathrm{CD}^{+} 6^{+}$cells, we further calculated the percentage of $\mathrm{CD}^{+}$and $\mathrm{CD}^{+} 6^{+}$cells expressing KIRs. There was no difference between the percentage of such cells among $\mathrm{CD}^{+}$cells and $\mathrm{CD} 6^{+}$cells, suggesting that IL-15 upregulated the expression of KIRs on both $\mathrm{CD}^{+}$and $\mathrm{CD} 16^{+}$cells, as did IL-2.

In conclusion, we demonstrated the effects of IL-15 on peripheral lymphocytes in human. IL-15 increased the NK activity, and expanded the population of $\mathrm{CD}_{16}{ }^{+} \mathrm{CD} 158 \mathrm{a}^{+} / \mathrm{b}^{+}$and $\mathrm{CD}^{+} \mathrm{CD} 158 \mathrm{a}^{+} / \mathrm{b}^{+}$cells, suggesting that IL-15 induces the effecter functions of resting NK cells throughout the whole body and thereby plays a critical role in the activation of tissueassociated immune responses.

ACKNOWLEDGEMENTS. The authors wish to thank S. Takagi and N. Kuribayashi for excellent assistance.

\section{References}

1. Wagtmann N, Biassoni R, Cantoni C, Verdiani S, Malnati MS, Vitale M, Bottino C, Moretta L, orreta A, Long EO. Molecular clones of the p58 NK cell receptor reveal immunoglobuline-related molecules with diversity in both the extra- and intracellular domains. Immunity 1995; 2: 439-449.

2. Colonna M, Samaridis J. Cloning of immunoglobulin-superfamily members associated with HLA-C and HLA-B recognition by human natural killer cells. Science 1995; 268: 405-408.

3. D'andrea A, Chang C, Franz-Bacon K, McClanahan T, Phillips JH, Lanier LL. Molecular cloning of NKB1 a natural killer cell receptor for HLA-B allotypes. J Immunol 1995; 155: 2306-2310.

4. Binstadt BA, Brumbaugh KM, Dick CJ, Scharenberg AM, Williams BL, Colonna M, Lanier LL, Kinet JP, Abraham RT, Leibson PJ. Sequential involvement of Lck and SHP-1 with MHC-recognizing receptors on NK cells inhibits FcR-initiated tyrosine kinase activation. Immunity 1996; 5 : 629-638.

5. Vivier E, Daeron M. Immunoreceptor tyrosine-based inhibition motifs. Immunol Today 1997; 18: 286-291.

6. Lanier LL. NK cell receptors. Annu Rev Immunol 1998; 16: 359-393.

7. Kogure T, Fujinaga H, Niizawa A, Le Xuan Hai, Shimada Y, Ochiai H, Terasawa K. Killer-cell inhibitory receptors, CD158a/b, are upregulated by interleukin-2, but not interferon- $\gamma$ or interleukin-4. Mediat Inflamm 1999; 8: 295-300

8. Grabstein KH, Eisenman J, Shanebeck K, Rauch C, Srinivasan S, Fung V, Beers C, Richardson J, Schoenborn MA, Ahdieh M, Johnson L, Alderson MR, Watson JD, Anderson DM, Giri JG. Cloning of a T cell growth factor that interacts with the beta chain of the interleukin-2 receptor. Science 1994; 264: 965-968.

9. Carson WE, Giri JG, Lindemann MJ, Linett ML, Ahdieh M, Paxton R, Anderson D, Eisenmann J, Grabstein JK, Caligiuli MA. Interleukin (IL) 15 is a novel cytokine that activates human natural killer cells via components of the IL-2 receptor. J Exp Med 1994; 180: 1395-1403.

10. Khan IA, Kasper LH. IL-15 augments CD8+ T cell-mediated immunity against Toxoplasma gondii infection in mice. J Immunol 1996; 157: 2103-2108.

11. Warren HS, Kinnear BF, Kastelein RL, Lanier LL. Analysis of the costimulatory role of IL-2 and IL-15 in initiating proliferation of resting (CD56dim) human NK cells. J Immunol 1996; 156: 3254-3259.

12. Armitage RJ, Macduff BM, Eisenman J, Paxton R, Grabstein KH. IL-15 has stimulatory activity for the induction of $\mathrm{B}$ cell proliferation and differentiation. J Immunol 1995; 154: 483-490.

13. Kanegane $H$, Tosato $G$. Activation of naive and memory $T$ cells by interleukin-15. Blood 1996; 88: 230-235.

14. Ogasawara $\mathrm{K}$, Hida $\mathrm{S}$, Azimi $\mathrm{N}$, Tagaya $\mathrm{Y}$, Sato $\mathrm{T}$, Yokochi-Fukuda $\mathrm{T}$, Waldmann TA, Taniguchi T, Taki S. Requirement for IRF-1 in the microenvironment supporting natural killer cell development. Nature 1998; 391: 700-703.

15. Puzanov I, Bennett M, Kumar V. IL-15 can substitute for the marrow microenvironment in the differentiation of natural killer cells. $J$ Immunol 1996; 157: 4282-4285.

16. Lodolce JP, Boone DL, Chai S, Swain RE, Dassopoulos T, Trettin S, Ma A. IL-15 receptor maintains lymphoid homeostasis by supporting lymphocyte homing and proliferation. Immunity 1998; 5: 669-676.

17. Carson WE, Fehninger TA, Haldar S, Eckhert K, Lindemann MJ, Lai CF Croce CM, Baumann H, Caligiuli MA. A potential role for interleukin-15 in the regulation of human natural killer cell survival. J Clin Invest 1997; 99: 937-943.

18. Ross G, Winchester RJ. Methods for enumerating lymphocyte population. In: Rose NR, Friedmann H, eds. Manual of Clinical Immunology. Washington, DC: American Society for Microbiology 1986: 213

19. Frohhn C, Schlenke P, Kirscner H. The repertoire of HLA-Cw-specific NK cell receptors CD158a/b (EB6 and GL183) in individuals with different HLA phenotypes. Immunology 1997; 92: 567-570. 
20. Agostini C, Trentin L, Sancetta R, Facco M, Tassinari C, Cerutti A, Bortolin M, Milani A, Siviero M, Zambello R, Semenzato G. Interleukin-15 triggers activation and growth of the CD8 T cell pool in extravascular tissues of patients with acuired immunodeficiency syndrome. Blood 1997; 90: 1115-1123.

21. Mcinnes IB, Al-Mughales J, Field M, Leung BP, Huang FP, Dixon R, Sturrock RD, Wilkinson PC, Liew FY. The role of interleukin-15 in T-cell migration and activation in rheumatoid arthritis. Nat Med 1996; 2: $175-182$.

22. Dunne J, Lynch S, O'Farrelly C, Todryk S, Hegarty JE, Feighry C, Doherty DG. Selective expansion and partial activation of human NK cells and NK receptor-positive T cells by IL-2 and IL-15. J Immunol 2001; 167: 3129-3138.

23. Bulfone-Paus S, Ungureanu D, Pohl T, Lindner G, Paus R, Ruckert R, Krause H, Kunzendorf U. Interleukin-15 protects from lethal apoptosis in vivo. Nat Med 1997; 3: 1124-1128.

24. Moretta L, Ciccone E, Moretta A, Hoglund P, Ohlen C, Karre K. Allorecognition by NK cells: nonself or self. Immunol Today 1992; 13: 300-303.

25. Yokoyama WM, Seaman WE. The Ly-49 and NKR-P1 gene families encoding lectin-like receptors on natural killer cells: the NK gene complex. Annu Rev Immunol 1993; 11: 613-635.
26. Lanier LL, Phillips JH. Inhibitory MHC class I receptors on NK cells and T cells. Immunol Today 1996; 17: 86-91.

27. Morreta A, Poggi A, Pende D, Tripodi G, Orengo AM, Pella N, Augugliaro R, Bottino C, Ciccone E, Morreta N. CD69-mediated pathway of lymphocyte activation: anti-CD69 monoclonal antibodies trigger the cytolytic activity of different lymphoid effector cells with the exception of cytolytic T lymphocytes expressing T cell receptor alpha/beta. J Exp Med 1991; 174: 1393-1398.

28. Nakajima H, Cella M, Langen H, Friedlein A, Colonna M. Activating interactions in human NK cell recognition: the role of 2B4-CD48. Eur J Immunol 1999; 29: 1676-1683.

29. Huard B, Karlsson L, Triebel F. KIR down-regulation on NK cells is associated with down-regulation of activating receptors and NK cell inactivation. Eur J Immunol 2001; 31: 1728-1735.

30. Warren HS, Cambell AJ, Waldron JC, Lanier LL. Biphasic response of NK cells expressing both activating and inhibitory killer Ig-like receptors. Int Immunol 2001; 13: 1043-1052.

\section{Received 1 March 2002 \\ Accepted 26 April 2002}




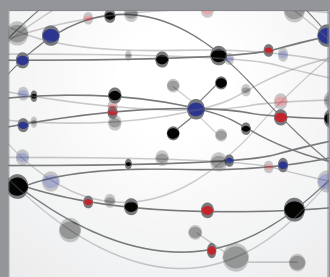

The Scientific World Journal
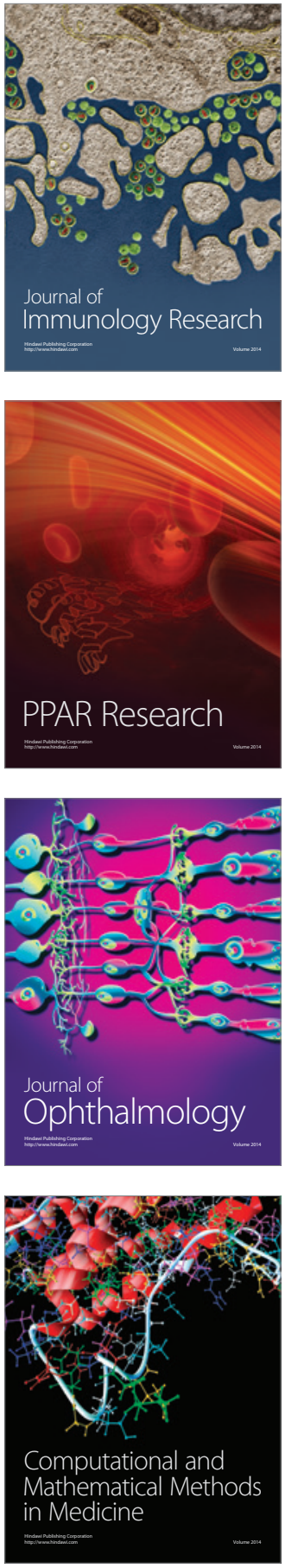

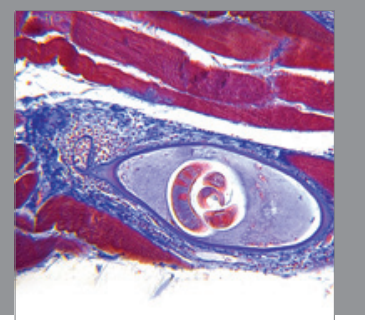

Gastroenterology

Research and Practice
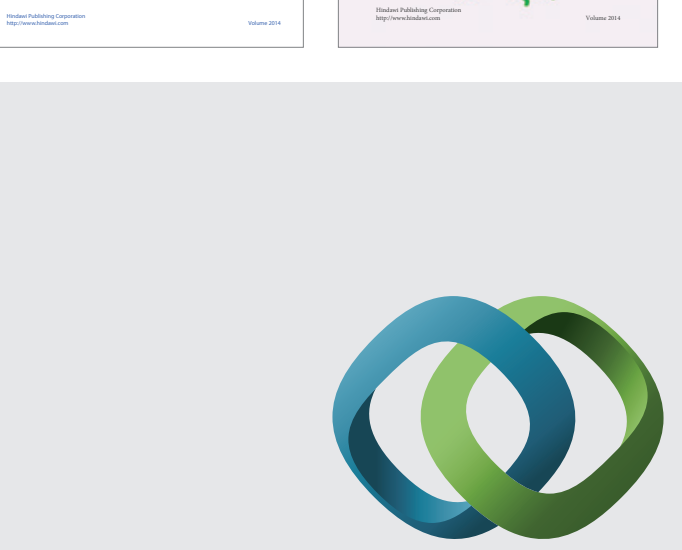

\section{Hindawi}

Submit your manuscripts at

http://www.hindawi.com
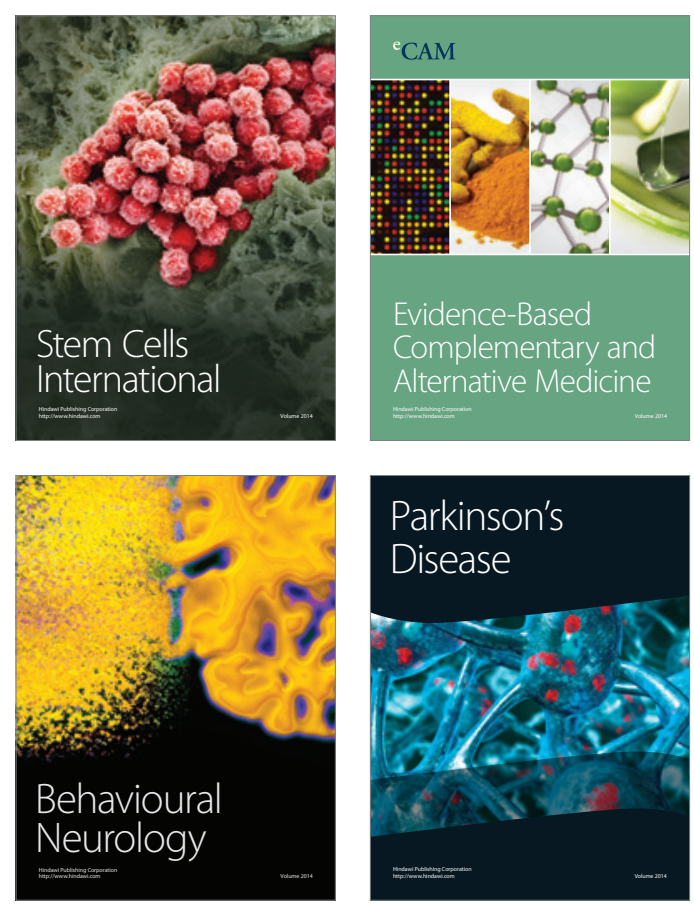

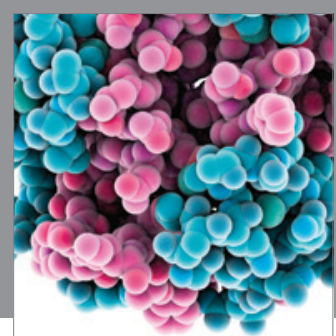

Journal of
Diabetes Research

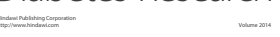

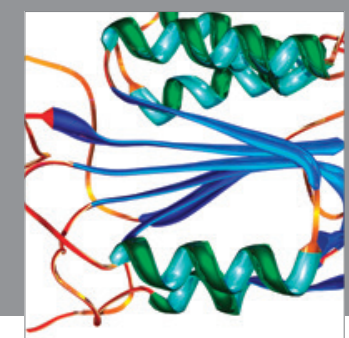

Disease Markers
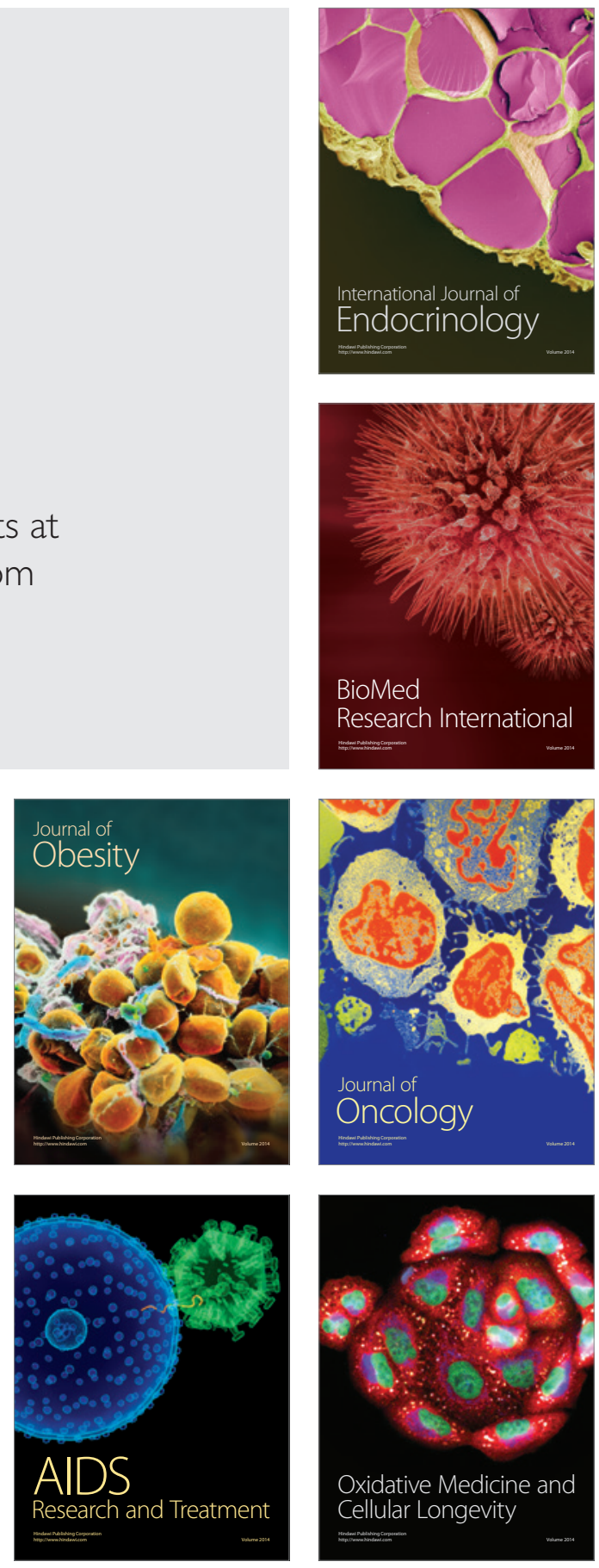